Revista Eletrônica de Direito Processual - REDP.

Rio de Janeiro. Ano 10. Volume 17. Número 2. Julho a Dezembro de 2016

Periódico Semestral da Pós-Graduação Stricto Sensu em Direito Processual da UERJ

Patrono: José Carlos Barbosa Moreira. ISSN 1982-7636. pp. 101-119 www.redp.uerj.br

\title{
O DEVER CONSTITUCIONAL DA FUNDAMENTAÇÃO DA SENTENÇA E O NOVO CÓDIGO DE PROCESSO CIVIL BRASILEIRO DE 2015: ESTUDO DE \\ CASO A RESPEITO DOS PRECEDENTES JUDICIAIS EM MATÉRIA CONSTITUCIONAL E O PADRÃO MÁXIMO DE FUNDAMENTAÇÃO NO DIREITO BRASILEIRO ${ }^{1}$
}

THE CONSTITUCIONAL DUTY OF REASONING THE JUDGMENTS AND THE NEW BRAZILIAN CIVIL PROCEDURE CODE OF 2015: STUDY OF A CASE RELATED TO PRECEDENTS CONCERNING CONSTITUTIONAL SUBJECT AND THE “MAXIMUM STANDARD” OF REASONING IN BRAZILIAN LAW

Professor Adjunto de Processo Civil da UFPR. Desembargador no TJPR. clayton.maranhao@hotmail.com

RESUMO: O presente artigo trata do dever de fundamentação das sentenças, revisto no novo Código de Processo Civil, especialmente analisado sob a ótica dos precedentes judiciais e institutos correlatos, tais como a distinção (distinguishing) e as razões de decidir (ratio decidendi).

PALAVRAS-CHAVE: precedentes; sentença; novo CPC; distinguishing; ratio decidendi; súmula vinculante 12 .

ABSTRACT: The present paper talks about the precedent's system, brought by the new Brazilian Civil Procedure Code, especially about distinguishing and ratio decidendi.

KEYWORDS: judicial precedent; distinguishing; ratio decidendi; Brazilian Civil Procedure Code.

SUMÁRIO: 1. Introdução. 2. Os enunciados de Súmula Vinculante do Supremo

\footnotetext{
${ }^{1}$ Artigo recebido em 08/06/2016 e aprovado em 20/09/2016.
} 
Revista Eletrônica de Direito Processual - REDP.

Rio de Janeiro. Ano 10. Volume 17. Número 2. Julho a Dezembro de 2016

Periódico Semestral da Pós-Graduação Stricto Sensu em Direito Processual da UERJ

Patrono: José Carlos Barbosa Moreira. ISSN 1982-7636. pp. 101-119

www.redp.uerj.br

Tribunal Federal como precedentes obrigatórios. 3. Os motivos determinantes da Súmula

Vinculante $\mathrm{n}^{\mathrm{o}} 12$ (ratio decidendi). 4. Modulação dos efeitos no controle difuso de constitucionalidade. 5. Fundamentação das decisões judiciais e distinção de casos (distinguishing). 6. Reafirmação dos precedentes mediante reiterada aplicação a casos subsequentes. 7. Considerações finais.

\section{INTRODUÇÃO}

O dever constitucional de fundamentação das decisões judiciais já era previsto desde 1988, nos termos do art. 93, inciso IX, da Constituição da República Federativa do Brasil, pelo qual "todos os julgamentos dos órgãos do Poder Judiciário serão públicos, e fundamentadas toda as decisões, sob pena de nulidade [...]." ${ }^{\prime 2}$

O Código de Processo Civil brasileiro de 1973, então vigente, fora recepcionado por essa Constituição, contudo, no que se refere à exigência de fundamentação, pode-se afirmar que impunha o padrão médio ${ }^{3}$ de fundamentação das decisões judiciais, quando, no art. 458, estatuiu que a sentença deveria conter relatório, fundamentação e dispositivo.

Com a entrada em vigor do novo Código de Processo Civil brasileiro (Lei $\mathrm{n}^{\circ}$ 13.105, de 16 de março de 2015, com vigência a partir de 18 de março de 2016), figurou dentre as principais novidades um standart de fundamentação das decisões judiciais num nível máximo, conectado com a inserção de um sistema de precedentes no direito brasileiro.

\footnotetext{
${ }^{2}$ Cf. a propósito do dever constitucional de fundamentação, o estudo de Michele Taruffo: Il significato costituzionale dell'obbligo di motivazione. In GRINOVER, Ada Pellegrini; DINAMARCO, Cândido Rangel; WATANABE, Kazuo (coord.). Participação e Processo. São Paulo: Revista dos Tribunais, 1988, p. 37-50. Sobre a teoria da motivação das decisões: TARUFFO, Michele. La motivación de la sentencia civil. Madrid: Editorial Trotta, 2011. Mais recentemente, sobre a redução do padrão de motivação no direito processual civil italiano, TARUFFO, Michele. Addio alla motivazione?In Rivista Trimestrale di Diritto e Procedura Civile, n.1, marzo 2014, p. 375-388.

${ }^{3}$ Como será visto no desenvolvimento deste trabalho, as decisões do Supremo Tribunal Federal sempre foram além desse padrão médio, cotejando os motivos determinantes dos precedentes e justificando as razões pelas quais eventualmente não seriam aplicáveis ao caso em julgamento mediante a técnica da distinção (distinguishing). Contudo, esse padrão decisório máximo nem sempre vinha sendo adotado nas instâncias ordinárias, precisamente por conta da recepção do CPC/73 pela Constituição de 1988, sem maiores exigências. Por conta das regras explicitadas no art. $489, \S 1^{\circ}$, incisos V e VI, bem assim do art. $927, \S 1^{\circ}$, do CPC/15, o padrão máximo do dever de motivação referido no texto também passou a ser exigível das instâncias ordinárias brasileiras, sob pena de nulidade (art. 10).
} 
Revista Eletrônica de Direito Processual - REDP.

Rio de Janeiro. Ano 10. Volume 17. Número 2. Julho a Dezembro de 2016

Periódico Semestral da Pós-Graduação Stricto Sensu em Direito Processual da UERJ

Patrono: José Carlos Barbosa Moreira. ISSN 1982-7636. pp. 101-119

www.redp.uerj.br

Esse padrão máximo de fundamentação das decisões judiciais no direito brasileiro

pode ser inferido do art. 489 do Novo Código de Processo Civil brasileiro de 2015 (CPC/15), pois, além de manter os elementos formais então estatuídos (relatório, fundamentação e dispositivo), ampliou as exigências, sob pena de nulidade.

Deveras, segundo o art. $489, \S 1^{\circ}$, do $\mathrm{CPC} / 15$ brasileiro, não se considera fundamentada qualquer decisão judicial (singular, monocrática ou colegiada, interlocutória ou final, provisória ou definitiva), que: $i$ ) se limite a indicar o artigo de lei, reproduzir ou parafrasear o texto da lei, sem explicar sua relação com a causa ou a questão decidida; ii) empregue conceitos vagos ou indeterminados, princípios ou cláusulas gerais sem explicar o motivo concreto de sua incidência no caso; iii) mencione motivos padronizados, passíveis de justificar qualquer outra decisão; $i v$ ) não enfrente todos os fundamentos de fato e de direito do autor controvertidos pelo réu, inclusive os argumentos e inferências que conectem ou desconectem a premissa maior à premissa menor do silogismo processual; $v$ ) se limite a invocar precedente judicial, sem identificar seus fundamentos determinantes nem demonstrar que o caso sob julgamento se ajusta àqueles fundamentos; vi) deixe de aplicar precedente judicial invocado pela parte, sem demonstrar a existência de distinção (distinguishing) no caso em julgamento ou a superação (overruling) do entendimento.

Outrossim, em caso de colisão de princípios constitucionais, o $§ 2^{\circ}$ do art. 489 do CPC/15 brasileiro expressamente estabelece a exigência de ponderação entre os bens jurídicos tutelados.

$\mathrm{O}$ art. 926 do novo $\mathrm{CPC} / 15$, por sua vez, define que os tribunais brasileiros devem uniformizar sua jurisprudência e mantê-la estável, íntegra e coerente, ao passo que o art. 927 define como de obrigatória observância pelos juízes e tribunais: i) as decisões do Supremo Tribunal Federal em controle concentrado de constitucionalidade; ii) os enunciados de súmula vinculante; iii) os acórdãos em incidente de assunção de competência ou de resolução de demandas repetitivas e em julgamento de recursos extraordinário e especial repetitivos; iv) os enunciados das súmulas do Supremo Tribunal Federal em matéria constitucional e do Superior Tribunal de Justiça em matéria infraconstitucional; v) a orientação do plenário ou do órgão especial aos quais estiverem vinculados. 
Revista Eletrônica de Direito Processual - REDP.

Rio de Janeiro. Ano 10. Volume 17. Número 2. Julho a Dezembro de 2016

Periódico Semestral da Pós-Graduação Stricto Sensu em Direito Processual da UERJ

Patrono: José Carlos Barbosa Moreira. ISSN 1982-7636. pp. 101-119

wWw.redp.uerj.br

Além disso, os parágrafos do art. 927 do novo CPC/15 estabelecem a conexão entre

o padrão máximo de fundamentação das decisões judiciais e o regime jurídico dos precedentes, inclusive da distinção de casos (distinguishing), da superação (overruling) e da modulação das decisões judiciais. ${ }^{4}$

Como se percebe das principais inovações no regime jurídico da fundamentação das decisões judiciais no direito brasileiro, há íntima conexão entre o padrão máximo ora imposto e o regime jurídico dos precedentes judiciais.

Dado os limites deste trabalho, não é possível um aprofundado estudo conceitual da jurisprudência, dos precedentes judiciais e das Súmulas no direito brasileiro o qual certamente é de valia inclusive para melhor compreensão do direito processual brasileiro.

Precisamente por isso, optou-se pela análise uma das hipóteses de precedentes obrigatórios arroladas no inciso II do art. 927 do CPC/15, e notadamente do enunciado de Súmula Vinculante editada pelo Supremo Tribunal Federal.

Como será visto a seguir, procedeu-se a um estudo de caso a partir do enunciado da Súmula Vinculante $\mathrm{n}^{\mathrm{o}}$ 12, editada pelo Supremo Tribunal Federal, com vistas a analisar os principais institutos precedentalistas.

\section{OS ENUNCIADOS DE SÚMULA VINCULANTE DO SUPREMO TRIBUNAL FEDERAL COMO PRECEDENTES OBRIGATÓRIOS}

Dispõe o art. 103-A da Constituição do Brasil que o Supremo Tribunal Federal pode editar Súmulas Vinculantes, após reiteradas decisões em matéria constitucional, ${ }^{5}$ instituto regulamentado pela Lei Federal n 11.417 , de 19 de dezembro de 2006.

\footnotetext{
${ }^{4} \S 1^{\circ}$ os juízes e os tribunais observarão o disposto no art. 10 e no art. $489, \S 1^{\circ}$, quando decidirem com fundamento neste artigo; $\S 2^{\circ}$ a alteração de tese jurídica adotada em enunciado de súmula ou em julgamento de casos repetitivos poderá ser precedida de audiências públicas e da participação de pessoas, órgãos ou entidades que possam contribuir para a rediscussão da tese; $\$ 3^{\circ}$ na hipótese de alteração de jurisprudência dominante do Supremo Tribunal Federal e dos tribunais superiores ou daquela oriunda de julgamento de casos repetitivos, pode haver modulação dos efeitos da alteração no interesse social e no da segurança jurídica; $\$ 4^{\circ}$ a modificação de enunciado de súmula, de jurisprudência pacificada ou de tese adotada em julgamento de casos repetitivos observará a necessidade de fundamentação adequada e específica, considerando os princípios da segurança jurídica, da proteção da confiança e da isonomia; §5o os tribunais darão publicidade a seus precedentes, organizando-os por questão jurídica decidida e divulgando-os, preferencialmente, na rede mundial de computadores.

${ }^{5}$ Art. 103-A. O Supremo Tribunal Federal poderá, de ofício ou por provocação, mediante decisão de dois terços dos seus membros, após reiteradas decisões sobre matéria constitucional, aprovar súmula que, a partir
} 
Revista Eletrônica de Direito Processual - REDP.

Rio de Janeiro. Ano 10. Volume 17. Número 2. Julho a Dezembro de 2016

Periódico Semestral da Pós-Graduação Stricto Sensu em Direito Processual da UERJ

Patrono: José Carlos Barbosa Moreira. ISSN 1982-7636. pp. 101-119

wWw.redp.uerj.br

O inciso II do art. 927 do CPC/15, como já afirmado, dispõe que os juízes e os tribunais observarão os enunciados de súmula vinculante do Supremo Tribunal Federal. ${ }^{6}$

No exercício desse poder-dever jurisprudencial, o STF aprovou o enunciado de Súmula Vinculante $\mathrm{n}^{\circ}$ 12, assim redigido: "A cobrança de taxa de matrícula nas universidades públicas viola o disposto no art. 206, IV, da Constituição Federal ${ }^{7 \text { ”. }}$

Podemos imaginar vários casos aparentemente análogos e que portanto sejam reconduzidos ao âmbito de proteção contido no enunciado da Súmula Vinculante $\mathrm{n}^{\mathbf{0}} 12$ (SV 12).

Suponha-se o caso em que seja cobrada taxa de matrícula de estudantes universitários ou mesmo cidadãos que pretendam inscrever-se em curso de língua estrangeira ofertado no âmbito de uma determinada universidade pública. Tenha-se presente, também, a cobrança de taxa de diploma para os bacharéis em direito, medicina, engenharia, ciências da computação ou qualquer outro curso ou programa ofertado em nível superior na mesma universidade pública.

À primeira vista, os dois casos se assemelham à medida que versam sobre a cobrança de taxas por serviços prestados em universidade pública, tida por indevida por força do contido no art. 206, IV, da Constituição Federal, e, portanto, se lhes aplicaria o enunciado da SV 12.

Contudo, na atual compreensão do texto constitucional pelo Supremo Tribunal Federal, os casos são considerados distintos.

Sem que se proceda a um juízo crítico a respeito dos critérios de justiça ou de validade das decisões que compõem a jurisprudência e os precedentes do STF a respeito

de sua publicação na imprensa oficial, terá efeito vinculante em relação aos demais órgãos do Poder Judiciário e à administração pública direta e indireta, nas esferas federal, estadual e municipal, bem como proceder à sua revisão ou cancelamento, na forma estabelecida em lei. $\S 1^{\circ}$-A súmula terá por objetivo a validade, a interpretação e a eficácia de normas determinadas, acerca das quais haja controvérsia atual entre órgãos judiciários ou entre esses e a administração pública que acarrete grave insegurança jurídica e relevante multiplicação de processos sobre questão idêntica. $\S 2^{\circ}$ Sem prejuízo do que vier a ser estabelecido em lei, a aprovação, revisão ou cancelamento de súmula poderá ser provocada por aqueles que podem propor a ação direta de inconstitucionalidade.

${ }^{6}$ Sobre a doutrina dos precedentes obrigatórios no direito processual brasileiro, cf. MARINONI, Luiz Guilherme. Precedentes Obrigatórios. São Paulo: Editora Revista dos Tribunais, 2010; idem, ibidem, 4. ed, 2016.

${ }^{7} \mathrm{O}$ inciso IV do art. 206 da Constituição do Brasil expressa o princípio da gratuidade do ensino público em estabelecimentos oficiais. 
Revista Eletrônica de Direito Processual - REDP.

Rio de Janeiro. Ano 10. Volume 17. Número 2. Julho a Dezembro de 2016

Periódico Semestral da Pós-Graduação Stricto Sensu em Direito Processual da UERJ

Patrono: José Carlos Barbosa Moreira. ISSN 1982-7636. pp. 101-119

www.redp.uerj.br

do tema, pretende-se expor as técnicas processuais dos precedentes a partir dos casos concretos que acorreram à Corte Suprema.

\section{OS MOTIVOS DETERMINANTES DA SÚMULA VINCULANTE $\mathbf{N}^{\circ} 12$ (RATIO DECIDENDI)}

Como se viu, o inciso II do art. 927 do CPC/15, numa interpretação meramente literal, conduz ao entendimento pelo qual os juízes e os tribunais observarão os enunciados de súmula vinculante do Supremo Tribunal Federal, e que, portanto, tais enunciados poderiam ser entendidos como um precedente.

Contudo, não é assim que se deve compreender o instituto do precedente judicial.

Registre-se, antes de tudo, que o precedente a respeito de uma determinada questão jurídica deve ser extraído dos motivos determinantes de uma ou mais decisões colegiadas emanadas das Cortes Supremas, no caso brasileiro do STF ou do STJ, segundo se trate de questão constitucional ou infraconstitucional, respectivamente.

Embora hipótese rara, é possível uma só decisão que sirva de base para a extração dos motivos determinantes de um precedente. Há o exemplo de precedente fundado nos motivos determinantes de um só acórdão que declare inconstitucional ato normativo federal questionado em ação direta decidida no Pleno do STF. Todavia, no plano discursivo, é recomendável que haja esgotamento argumentativo do tema para que se tenha motivação determinante transcendente ao caso. ${ }^{8}$

Em realidade, não se há de confundir, dentre os casos repetitivos, aqueles cuja técnica processual de decisão não implica cisão na cognição (recursos repetitivos), e em que há cisão no julgamento (incidente de resolução de demandas repetitivas). No caso dos

\footnotetext{
${ }^{8}$ Define-se como premissa essencial de aplicação de precedentes, dentre outras, a seguinte: “Esgotamento prévio da temática antes de sua utilização como um padrão decisório (precedente): ao se proceder à análise de aplicação dos precedentes no commom law se percebe ser muito difícil a formação de um precedente (padrão decisório a ser repetido) a partir de um único julgado, salvo se em sua análise a formação de um esgotamento discursivo de todos os aspectos relevantes suscitados pelos interessados. Nestes termos, mostra-se estranha a formação de um 'precedente' a partir de um julgamento superficial de um (ou poucos) recursos (especiais elou extraordinários) pinçados pelos Tribunais (de Justiça/regionais ou Superiores). Ou seja, precedente (padrão decisório) dificilmente se forma a partir de um único julgado." NUNES, Dierle; BAIA, Alexandre Melo Franco. Precedentes no CPC-2015: por uma compreensão constitucionalmente adequada do seu uso no Brasil. In FREIRE, Alexandre; BARROS, Lucas Buril de Macedo; PEIXOTO, Ravi. Coletânea Novo CPC: Doutrina Selecionada. Salvador: JusPodivm, 2015.
} 
Revista Eletrônica de Direito Processual - REDP.

Rio de Janeiro. Ano 10. Volume 17. Número 2. Julho a Dezembro de 2016

Periódico Semestral da Pós-Graduação Stricto Sensu em Direito Processual da UERJ

Patrono: José Carlos Barbosa Moreira. ISSN 1982-7636. pp. 101-119

www.redp.uerj.br

recursos repetitivos, os processos que serão afetados como representativos da controvérsia devem ser selecionados dentre os que contenham abrangente argumentação e discussão a respeito da questão a ser decidida e a respeito da qual formar-se-á um precedente.

Feita a ressalva, não há necessidade de casos repetitivos para que se tenha um precedente judicial, muito embora um precedente possa auxiliar na gestão do acervo processual repetitivo nas instâncias ordinárias. ${ }^{9}$ As demandas de massa são enfrentadas por meio de outras técnicas processuais que não são objeto deste ensaio (v.g., incidente de resolução de demandas repetitivas). Fique claro, todavia, que para a edição de súmula vinculante é necessário que haja multiplicação de processos sobre idêntica questão constitucional e que a respeito se tenha divergência jurisprudencial.

Precedente não se confunde com enunciado de súmula vinculante.

Justamente por isso, o art. 926, caput, do CPC/15 exorta que os tribunais devem uniformizar sua jurisprudência e mantê-la estável, íntegra e coerente, estipulando regra fundamental para a compreensão do que seja precedente no $\S 2^{\circ}$ do referido artigo, assim redigido: "Ao editar enunciados de súmula, os tribunais devem ater-se às circunstâncias fáticas dos precedentes que motivaram sua criação".

É que o precedente não se encontra no enunciado da súmula, mas nos múltiplos processos sobre idêntica questão que serviram de base para a instauração do procedimento, ainda que autônomo, de edição da súmula vinculante (art. $2^{\circ}$ da Lei 11.417/06).

Em outras palavras, a ratio decidendi deve ser buscada junto às circunstâncias fáticas dos casos precedentes à formação do enunciado da súmula vinculante.

Segundo a doutrina, "motivo determinante, assim, é o motivo que, considerado na fundamentação, mostra-se imprescindível à decisão que foi tomada. Este motivo, por imprescindivel, é essencial, ou melhor, é determinante da decisão."10

\footnotetext{
9 Como ressaltado na doutrina, "a) o sistema de precedentes se estruturou historicamente muito anteriormente ao (e pois, totalmente à revelia do) surgimento da nominada litigiosidade repetitiva; $b$ ) uma técnica de causa piloto ou de procedimento modelo somente terá condições de formar precedentes se a deliberação se der de tal modo que todos os argumentos relevantes sejam levados em consideração (como prescrevem os arts. 10 e 489, $\$ 1^{\circ}$, inc. IV, 927, $\left.\$ 1^{\circ}, C P C-2015\right)$ '. NUNES, Dierle; BAIA, Alexandre Melo Franco. Precedentes no CPC-2015: por uma compreensão constitucionalmente adequada do seu uso no Brasil. In NUNES, Dierle; BAIA, Alexandre Melo Franco. Precedentes no CPC-2015: por uma compreensão constitucionalmente adequada do seu uso no Brasil. In FREIRE, Alexandre; BARROS, Lucas Buril de Macedo; PEIXOTO, Ravi. Coletânea Novo CPC: Doutrina Selecionada. Salvador: JusPodivm, 2015.

${ }^{10}$ MARINONI, Luiz Guilherme. Precedentes Obrigatórios. São Paulo: RT, 2010, p. 292.
} 
Revista Eletrônica de Direito Processual - REDP.

Rio de Janeiro. Ano 10. Volume 17. Número 2. Julho a Dezembro de 2016

Periódico Semestral da Pós-Graduação Stricto Sensu em Direito Processual da UERJ

Patrono: José Carlos Barbosa Moreira. ISSN 1982-7636. pp. 101-119

www.redp.uerj.br

Outro problema reside na identificação da ratio decidendi, isto é, dos motivos

determinantes dos precedentes que serviram de base ao enunciado. Eventualmente, o enunciado da súmula poderá ter uma função de esclarecimento.

Serve-se novamente da doutrina:

"De outro lado, a facilidade de identificação da ratio decidendi varia de caso a

caso. A dificuldade de individualização da ratio decidendi pode decorrer da circunstância de o caso ter de ser analisado sob argumentos não deduzidos pelas partes; da complexidade da matéria; de os fundamentos terem sido analisados de modo prematuro; da superficialidade das discussões e da elaboração dos fundamentos; da variedade e diversidade de fundamentos apresentados nos votos proferidos pelos membros do órgão judicial, entre outras. Assim, a definição da ratio decidendi pode exigir, em algumas hipóteses, a consideração de várias decisões, e, em outras, de súmula - que, sobrepondo-se às decisões já proferidas sobre o caso, individualize a ratio decidendi, até então obscura e indecifrável ${ }^{11}$."

Contudo, mais adiante, faz-se a ressalva:

"A súmula vinculante só pode ser editada quando houver controvérsia atual. Entretanto, por controvérsia atual não basta entender questão constitucional que está em discussão, ou que acaba de ser discutida, no Supremo Tribunal Federal. A controvérsia é atual quando há discussão, contemporânea, acerca da precisa ratio decidendi dos precedentes que dizem respeito a uma mesma questão constitucional. Controvérsia, portanto, não é sinônimo de objeto sobre o qual se discute judicialmente, mas pertine à dúvida sobre a ratio decidendi dos precedentes respeitantes tal objeto. Ora, se os precedentes, uma vez proferidos, não geram dúvida quanto à ratio decidendi, não há razão para editar súmula ${ }^{12}$."

Calha, então, breve análise a respeito da conveniência na edição da SV 12 pelo STF. Da leitura dos precedentes, havia dúvida fundada sobre os motivos determinantes que lhes serviram de base, a exigir esclarecimento por meio da edição de súmula?

Como será demonstrado no decorrer da exposição, parece ter sido oportuna a edição da súmula por duas razões: $(i)$ primeiro, porque a questão relativa à gratuidade dos

\footnotetext{
${ }^{11}$ MARINONI, Luiz Guilherme. Op. Cit., p. 293.

${ }^{12}$ MARINONI, Luiz Guilherme. Op. Cit., p. 488.
} 
Revista Eletrônica de Direito Processual - REDP.

Rio de Janeiro. Ano 10. Volume 17. Número 2. Julho a Dezembro de 2016

Periódico Semestral da Pós-Graduação Stricto Sensu em Direito Processual da UERJ

Patrono: José Carlos Barbosa Moreira. ISSN 1982-7636. pp. 101-119

www.redp.uerj.br

serviços educacionais prestados por universidade pública, embora não seja de uma complexidade tal que pudesse ensejar falta de clareza na fundamentação determinante das decisões em que se formaram os precedentes, envolveu uma multiplicidade de casos que tornou premente a súmula ao tempo em que foi editada; (ii) segundo, porque a questão esgotou quase todos argumentos, remanescendo apenas um caso pendente de julgamento atualmente no pleno do STF, já com repercussão geral admitida.

Feitas essas considerações, o STF parece ter definido a ratio decidendi da SV 12, a partir dos seguintes motivos constantes da fundamentação de um dos precedentes que lhe serviram de base:

"(...) a gratuidade de ensino público em estabelecimentos oficiais, conforme se lê no caput do art. 206, IV, configura um princípio. Um princípio que não encontra qualquer limitação, no tocante aos distintos graus de formação acadêmica. (...) O que não se mostra factível, do ponto de vista constitucional, é que as universidades públicas, integralmente mantidas pelo Estado, criem obstáculos de natureza financeira para o acesso dos estudantes aos cursos que ministram, ainda que de pequena expressão econômica, a pretexto de subsidiar alunos carentes, como ocorre no caso dos autos. (...) Não se figura razoável, ademais, que se cobre uma taxa de matrícula dos estudantes das universidades públicas, em especial das federais, visto que a Constituição, no art. 212, determina à União, que aplique, anualmente, nunca menos de $18 \%$ da receita resultante de impostos, na manutenção e desenvolvimento do ensino." (STF, RE 500.171, Rel. Min. Ricardo Lewandowski, Tribunal Pleno, julgamento em 13.8.2008, DJe de 24.10.2008.) $)^{13}$

Como se vê dos motivos determinantes do precedente citado, inicialmente há menção de âmbito mais geral no sentido da "gratuidade do ensino público em estabelecimentos oficiais", para, em seguida, referir-se ao "impedimento de as universidades públicas criarem obstáculos de natureza financeira para o acesso dos estudantes aos cursos ofertados", e, finalmente, ter-se como vedado "cobrar taxa de matrícula dos estudantes das universidades públicas, diante dos percentuais mínimos do orçamento público vinculados à educação."

${ }^{13} \mathrm{Cf}$. http://stf.jus.br/portal/jurisprudencia/menuSumario.asp?sumula=1223\&termo=, acesso em 15 de abril de 2016. As demais referências à SV 12 neste trabalho também foram extraídas do sítio do STF. 
Revista Eletrônica de Direito Processual - REDP.

Rio de Janeiro. Ano 10. Volume 17. Número 2. Julho a Dezembro de 2016

Periódico Semestral da Pós-Graduação Stricto Sensu em Direito Processual da UERJ

Patrono: José Carlos Barbosa Moreira. ISSN 1982-7636. pp. 101-119 www.redp.uerj.br

Consigne-se que quando os motivos não configuram um passo necessário para a decisão, eles não são determinantes e, portanto, sendo prescindíveis, não precisariam estar afirmados na fundamentação da decisão judicial (obiter dictum).

Ter essa compreensão dos precedentes é fundamental para que se possa cumprir com as exigências postas pelo art. 489, §1º, incisos V e VI novo Código de Processo Civil de 2015, que por sua vez concretizam um padrão máximo do dever constitucional de fundamentação das decisões judiciais ${ }^{14}$.

\section{MODULAÇÃO DOS EFEITOS NO CONTROLE DIFUSO DE CONSTITUCIONALIDADE}

Ainda que se reconheça que a declaração de inconstitucionalidade se situe no âmbito das nulidade, e que portanto via de regra tenha efeito retroativo (ex tunc), certo é que a doutrina e a jurisprudência do STF vem reconhecendo possível a modulação dos efeitos, seja no controle concentrado ou no difuso, este último por força de aplicação analógica do art. 27 da Lei 9.868/99, quando não pela ponderação de princípios. ${ }^{15}$ Há também o disposto no art. $927, \S 3^{\circ}$, do $\mathrm{CPC} / 15$, tendo em vista o interesse social e a segurança jurídica ${ }^{16}$.

No precedente que serviu de base à edição do enunciado da SV 12, o STF fora instado a modular os efeitos do acórdão (ex nunc), via embargos de declaração, acolhidos nos seguintes termos:

"(...) II - Modulação dos efeitos da decisão que declarou a inconstitucionalidade da cobrança da taxa de matrícula nas universidades públicas a partir da edição da Súmula Vinculante 12, ressalvado o direito daqueles que já haviam ajuizado ações com o mesmo objeto jurídico. (...)" (STF, ED no RE 500.171, Rel. Min. Ricardo Lewandowski, Tribunal Pleno, julgamento em 16.3.2011, DJe de 3.6.2011, maioria.)

\footnotetext{
${ }^{14}$ [Art. 489, $\S 1^{\circ}$ ] V - se limitar a invocar precedente ou enunciado de súmula, sem identificar seus fundamentos determinantes nem demonstrar que o caso sob julgamento se ajusta àqueles fundamentos; VI deixar de seguir enunciado de súmula, jurisprudência ou precedente invocado pela parte, sem demonstrar a existência de distinção no caso em julgamento ou a superação do entendimento.

${ }^{15}$ BARROSO, Luis Roberto. O Controle de Constitucionalidade no Direito Brasileiro. 6. ed. São Paulo: Saraiva, 2014, p. 151-154.

16 ÁVILA, Humberto. Teoria da Segurança Jurídica. 3. ed. São Paulo: Malheiros, 2014, pp. 534-595.
} 
Revista Eletrônica de Direito Processual - REDP.

Rio de Janeiro. Ano 10. Volume 17. Número 2. Julho a Dezembro de 2016

Periódico Semestral da Pós-Graduação Stricto Sensu em Direito Processual da UERJ

Patrono: José Carlos Barbosa Moreira. ISSN 1982-7636. pp. 101-119

www.redp.uerj.br

Em caso posterior, o STF reafirmou a modulação dos efeitos:

"4. Cumpre mencionar que, em 16.3.2011, este Supremo Tribunal, por maioria, acolheu os embargos de declaração opostos no Recurso Extraordinário n. 500.171, para atribuir efeitos ex nunc à declaração de inconstitucionalidade da cobrança da taxa em debate. (...) Decidiu-se, também, que seriam resguardados os direitos dos estudantes que tivessem ingressado individualmente em juízo para pleitear o seu ressarcimento, não sendo autorizada, apenas, a devolução em massa pelas universidades públicas." (STF, AgR no RE 563.386, Rel. Min. Carmen Lúcia, Primeira Turma, julgamento em 14.6.2011, DJe de 1.7.2011.)

\section{FUNDAMENTAÇÃO DAS DECISÕES JUDICIAIS E DISTINÇÃO DE CASOS (DISTINGUISHING)}

Como visto, dentre as novas exigências do dever de fundamentação das decisões judiciais postas no direito brasileiro, figura a de justificar a conexão do caso com os motivos determinantes do precedente tido como aplicável, bem como a de demonstrar a distinção do caso em julgamento com as peculiaridades fático-jurídicas dos precedentes que serviram de base para o precedente invocado pelas partes (Art. 489, $\S 1^{\circ}$, incisos V e VI, CPC/15).

Não se olvide que o $\$ 2^{\circ}$ do art. 926 do $\mathrm{CPC} / 15$ estabelece que "ao editar enunciados de súmula, os tribunais devem ater-se às circunstâncias fáticas dos precedentes que motivaram a sua criação".

Nessa linha de raciocínio, a distinção de casos (distinguishing) é uma técnica de aplicação dos precedentes. Para que haja efeito vinculante (doctrine of binding precedents $),{ }^{17}$ os motivos determinantes do precedente e do caso a ser julgado devem ser comparados entre si.

Tal técnica pode ser aplicada motivadamente pelos juízes e tribunais de segundo grau de jurisdição para afastar a incidência do precedente obrigatório (stare decisis

\footnotetext{
${ }^{17}$ MACEDO, Lucas Buril de. Precedentes judiciais e o direito processual civil. Salvador: JusPodivm, 2015, p. 61.
} 
Revista Eletrônica de Direito Processual - REDP.

Rio de Janeiro. Ano 10. Volume 17. Número 2. Julho a Dezembro de 2016

Periódico Semestral da Pós-Graduação Stricto Sensu em Direito Processual da UERJ

Patrono: José Carlos Barbosa Moreira. ISSN 1982-7636. pp. 101-119

www.redp.uerj.br

vertical), assim como pelo Ministro Relator e demais integrantes do colegiado no STF (stare decisis horizontal) $^{18}$.

Como visto, da ratio decidendi do precedente que serviu de base ao enunciado da SV 12, diante do princípio da gratuidade do ensino público em estabelecimentos oficiais, o STF considerou indevida a cobrança de taxa de matrícula em universidade pública.

Ocorre que, após a edição da SV 12, deparou-se o Pleno do STF com um caso em que uma universidade pública brasileira havia ofertado alguns cursos de línguas estrangeiras no âmbito de um programa de extensão universitária, cobrando para tanto taxa de matrícula. Nas instâncias ordinárias, a liminar foi deferida com fundamento na SV 12.

Contudo, o Min. Relator Gilmar Mendes operou a distinção dos casos e determinou a suspensão da liminar, mediante a seguinte justificativa:

"À primeira vista, afigura-se plausível a pretensão do reclamante no sentido de que a decisão impugnada teria aplicado indevidamente o enunciado da Súmula Vinculante $n^{\mathbf{o}}$ 12: (...) Isso porque, da análise dos autos, pode-se constatar que a reclamante, Universidade Federal do Ceará, está cobrando taxa de matrícula para os cursos de línguas estrangeiras, realizados dentro do Projeto 'Casas de Cultura Estrangeira' (fls. 55-56), e não para a matrícula em seus cursos de graduação. A análise dos precedentes desta Suprema Corte que motivaram a aprovação da Súmula Vinculante $\mathrm{n}^{\circ} \mathbf{1 2}$ não tratam de qualquer curso realizado pelas universidades públicas, mas apenas dos cursos de ensino superior. (...) Ante o exposto, defiro a medida liminar para suspender a decisão (...)". (STF, Rcl na MC 8.596. Rel. Min. Gilmar Mendes, julgamento em 10.7.2009, Decisão Monocrática, DJe de 5.8.2009).

Como assevera a doutrina, "o surgimento de uma nova situação, não tratada nos precedentes que deram origem à Súmula, pode não impor o overruling, mas o distinguishing ${ }^{19}$ ".

\footnotetext{
${ }^{18}$ In NUNES, Dierle; BAIA, Alexandre Melo Franco. Precedentes no CPC-2015: por uma compreensão constitucionalmente adequada do seu uso no Brasil. In FREIRE, Alexandre; BARROS, Lucas Buril de Macedo; PEIXOTO, Ravi. Coletânea Novo CPC: Doutrina Selecionada. Salvador: JusPodivm, 2015, passim.

${ }^{19}$ MARINONI, Luiz Guilherme. Op. Cit., p. 356.
} 
Revista Eletrônica de Direito Processual - REDP.

Rio de Janeiro. Ano 10. Volume 17. Número 2. Julho a Dezembro de 2016

Periódico Semestral da Pós-Graduação Stricto Sensu em Direito Processual da UERJ

Patrono: José Carlos Barbosa Moreira. ISSN 1982-7636. pp. 101-119

www.redp.uerj.br

No caso vertente, pois, houve aplicação da técnica de distinção quando, prima facie, entendeu-se por não se aplicar a SV 12. Percebe-se que muito antes da vigência do CPC/15 a Suprema Corte brasileira já tinha como padrão de exigência do dever de motivação de suas decisões mediante o enfrentamento das razões pelas quais um precedente não seria aplicável porque o caso em julgamento seria distinto.

Todavia, situações há em que tal situação não se mostra tão clara, e por isso conducente à aplicação de uma distinção inconsistente, ou seja, uma exceção indevida ao precedente (inconsistent distinguishing). É como se a regra incidisse, mas o tribunal lhe negasse aplicação. E quando a distinção inconsistente se dá no próprio tribunal do qual emanou o precedente, afirma-se que nesse caso há uma superação parcial (overriding) ${ }^{20}$. A seguir veremos casos subseqüentes à edição do enunciado da SV 12 pelo STF, uma delas, inclusive, de distinção inconsistente. Em quaisquer dessas situações, há o dever de fundamentação no padrão máximo agora exigido pelo CPC/15.

\section{REAFIRMAÇÃO DOS PRECEDENTES MEDIANTE REITERADA APLICAÇÃO A CASOS SUBSEQUENTES}

Diante da distinção ou até superação parcial do precedente que serviu de base para a SV 12, poder-se-ia cogitar da subsistência da Súmula e da possível sinalização ou desgaste do precedente, tendente à revisão ou cancelamento do enunciado, nos termos da Lei 11.417/06 e, a partir da vigência do CPC/15, também com fundamento no art. 927, §4º.

Tais situações de distinção e superação de precedentes são, agora, explicitamente exigidas nos incisos V e VI do art. 489 do CPC/15.

Contudo, mesmo antes da vigência do $\mathrm{CPC} / 15$, inúmeros casos foram julgados pelo STF reafirmando a facticidade da SV 12, senão vejamos.

A respeito da cobrança de taxa de matrícula por universidade pública, a Suprema Corte assim vem decidindo:

"O Plenário deste Tribunal fixou entendimento no sentido de que a exigência da cobrança de taxa de matrícula nas universidades públicas viola o disposto no artigo 206, IV, da Constituição do Brasil [Súmula Vinculante n. 12]. (...)" (STF, AI

\footnotetext{
${ }^{20}$ MACEDO, Lucas Buril de. Precedentes judiciais e o direito processual civil. Op. Cit., p. 366.
} 
Revista Eletrônica de Direito Processual - REDP.

Rio de Janeiro. Ano 10. Volume 17. Número 2. Julho a Dezembro de 2016

Periódico Semestral da Pós-Graduação Stricto Sensu em Direito Processual da UERJ

Patrono: José Carlos Barbosa Moreira. ISSN 1982-7636. pp. 101-119

www.redp.uerj.br

672.123, Rel. Min. Eros Grau, Segunda Turma, julgamento em 1.12.2009, DJe de

18.12.2009). No mesmo sentido: RE 581.669, Rel. Min. Dias Toffoli, Decisão Monocrática, DJe de 6.3.2013; RE 543.150, Rel. Min. Dias Toffoli, Decisão Monocrática, DJe de 26.8.2011.

No que se refere à cobrança de taxa para atividade-fim:

4. Tenho que a insurgência não merece acolhida. Isso porque, conforme consta do parecer proferido pelo ministério público federal, a educação é um direito de todos e dever do Estado, não tendo a Constituição Republicana se restringido a gratuidade do ensino público apenas ao nível fundamental. Leia-se o seguinte trecho do referido parecer: '(...) embora promovida e incentivada com a colaboração da sociedade, não se autoriza, ao estabelecimento de ensino público, a cobrança pela prestação de serviço vinculado à sua atividade fim, pois, entre as várias competências privativas da União, infere-se do artigo 22, inciso XXIV, da Carta Magna, que o acesso ao processo de desenvolvimento intelectual tem importância estratégica para a existência do Estado. Logo, não pode ser totalmente entregue à iniciativa privada ou ofertado, exclusivamente, aos mais abastados. (...). De outro modo, ainda que as razões acima não sejam suficientes para dirimir a quaestio iuris, a autonomia da Universidade, prevista no artigo 207 da Lei Suprema, não pode ser interpretada como independência e, muito menos soberania, pois está jungida aos lindes da legalidade e constitucionalidade, restando, assim, indevida a cobrança de mensalidade, taxa ou qualquer instrumento remuneratório que não esteja disciplinado pela União'. 5. Para arrematar, invoco a Súmula Vinculante 12, que trata do tema da gratuidade do ensino público em sentido amplo, a afastar a incidência de quaisquer cobranças, ainda que vinculadas mediatamente à regra constitucional posta no inciso IV do art. 206 da Constituição Federal (...)." (STF, RE 571.660, Rel. Min. Ayres Britto, Decisão Monocrática, julgamento em 17.10.2011, DJe de 4.11.2011).

Da mesma forma, tem-se como vedado pela SV 12 a cobrança de taxa para o concurso vestibular ou realização de teste seletivo: 
Revista Eletrônica de Direito Processual - REDP.

Rio de Janeiro. Ano 10. Volume 17. Número 2. Julho a Dezembro de 2016

Periódico Semestral da Pós-Graduação Stricto Sensu em Direito Processual da UERJ

Patrono: José Carlos Barbosa Moreira. ISSN 1982-7636. pp. 101-119 www.redp.uerj.br

"Taxa de inscrição em processo seletivo seriado - Ingresso no ensino superior Universidade pública - Artigo 206, inciso IV, da Constituição Federal. O mesmo raciocínio utilizado na elaboração do Verbete Vinculante $\mathrm{n}^{\mathbf{0}} \mathbf{1 2}$ deve ser observado nas hipóteses de cobrança de taxa para inscrição de processo seletivo seriado em Universidade Pública, considerada a gratuidade do ensino público em estabelecimentos oficiais." (STF, AI 748.944, Rel. Min. Marco Aurélio, Primeira Turma, julgamento em 5.8.2014, DJe de 26.8.2014).

No entanto, a respeito de cobrança de taxa para prestação teste seletivo, parece ter havido uma distinção inconsistente no seguinte julgado do STF:

"Vislumbro, neste juízo prévio, o confronto entre o ato emanado do juízo reclamado e o que expressamente dispõe a Súmula Vinculante $\mathrm{n}^{\mathrm{o}} 12$, verbis: “A cobrança de taxa de matrícula nas universidades públicas viola o disposto no art. 206, IV, da Constituição Federal." (DOU 22.5.2008, negritei). É que, ao julgar o RE 500.171/GO, rel. Min. Ricardo Lewandowski, DJE 23.10.2008, que originou a referida súmula, o Plenário desta Suprema Corte estabeleceu que a cobrança de matrícula para cursar a universidade é que ofende o art. 206, IV, da Constituição Federal, e não a taxa cobrada para inscrição em processo de seleção. Quanto ao perigo na demora, verifico que o REOMS n ${ }^{\circ}$ 2006.39.00.009780-0 se encontra em grau de agravo de instrumento para o Supremo tribunal. 4. Ante o exposto, defiro o pedido de liminar, para suspender a decisão proferida no REOMS $\mathrm{n}^{\circ}$ 2006.39.00.009780-0 pela Presidência do Tribunal Regional Federal da 1 ${ }^{\text {a }}$ Região, até o julgamento final da presente reclamação. (STF, Rcl na MC 7831, Rel. Min. Ellen Gracie, Decisão Monocrática, julgamento em 6.4.2009, DJe de 16.4.2009).

Noutros casos, aplicou-se a SV 12 para vedar a cobrança de taxa de expedição de diploma de universidade pública:

"Nesse contexto, cumpre ressaltar que, da mesma forma que a matrícula constitui formalidade essencial para que o aluno tenha acesso à educação superior, o diploma representa documento imprescindível ao exercício de determinadas profissões. $\mathrm{O}$ que não se mostra factível, do ponto de vista constitucional, é que as universidades 
Revista Eletrônica de Direito Processual - REDP.

Rio de Janeiro. Ano 10. Volume 17. Número 2. Julho a Dezembro de 2016

Periódico Semestral da Pós-Graduação Stricto Sensu em Direito Processual da UERJ

Patrono: José Carlos Barbosa Moreira. ISSN 1982-7636. pp. 101-119

www.redp.uerj.br

públicas, integralmente mantidas pelo Estado, criem obstáculos de natureza financeira para a expedição de diploma aos estudantes dos cursos que ministram, ainda que de pequena expressão econômica, a pretexto de subsidiar alunos carentes, como ocorre no caso dos autos." (STF, RE 593.733, Relator Ministro Ricardo Lewandowski, Decisão Monocrática, julgamento em 22.3.2011, DJe de 29.3.2011).

"Taxa para expedição de diploma - Universidade pública - Artigo 206, inciso IV, da Constituição Federal. O mesmo raciocínio utilizado na elaboração do Verbete Vinculante $\mathrm{n}^{\circ} \mathbf{1 2}$ deve ser observado nas hipóteses de cobrança de taxa para inscrição de processo seletivo seriado em Universidade Pública, considerada a gratuidade do ensino público em estabelecimentos oficiais. (...) $\mathrm{O}$ Tribunal, no Recurso Extraordinário $\mathrm{n}^{\circ}$ 562.779/DF, da relatoria do ministro Ricardo Lewandowski, sob o ângulo da repercussão geral, assentou a inconstitucionalidade da cobrança de taxa de matrícula como requisito para ingresso em universidade federal, por representar violação ao artigo 206, inciso IV, da Carta da República. Consignou constituir a matrícula formalidade essencial para acesso do aluno à educação superior, de modo que se apresenta inadequada qualquer limitação ao princípio constitucional do ensino público gratuito nos estabelecimentos oficiais. $\mathrm{Na}$ ocasião, votei com a maioria, ressaltando a ideia básica que serve de causa ao princípio: viabilizar o acesso dos que não podem cursar o nível superior sem prejuízo do próprio sustento e da família. Nesse sentido, o Pleno aprovou o Verbete Vinculante $\mathrm{n}^{\circ}$ 12. O mesmo raciocínio e conclusão devem ser empregados no caso de cobrança de taxa para expedição de diploma." (STF, AgR no RE 597.872, Rel. Min. Marco Aurélio, Primeira Turma, julgamento em 3.6.2014, DJe de 26.8.2014).

Da mesma forma, no que se refere à taxa de alimentação em instituição pública de ensino profissionalizante:

"A interpretação conjunta dos citados artigos 206, inciso IV, e 208, inciso VI, revela, a mais não poder, que programa de alimentação de estudantes em instituição pública de ensino profissionalizante que se apresente oneroso a estes consiste na própria negativa de adoção do programa. O princípio constitucional da gratuidade de ensino público em estabelecimento oficial alcança não apenas o ensino em si, 
Revista Eletrônica de Direito Processual - REDP.

Rio de Janeiro. Ano 10. Volume 17. Número 2. Julho a Dezembro de 2016

Periódico Semestral da Pós-Graduação Stricto Sensu em Direito Processual da UERJ

Patrono: José Carlos Barbosa Moreira. ISSN 1982-7636. pp. 101-119

www.redp.uerj.br

mas também as garantias de efetivação do dever do Estado com a educação previsto

na Constituição e, entre essas, o atendimento ao educando em todas as etapas da educação básica, incluído o nível médio profissionalizante, fornecendo-lhe alimentação. $O$ envolvimento, na espécie, de autarquia federal de ensino profissional conduz à impossibilidade da cobrança pretendida. Conclusão diversa, como a atacada por meio deste recurso, distorce o sistema de educação pública gratuita consagrado na Carta da República". (STF, RE 357.148, Rel. Min. Marco Aurélio, Primeira Turma, julgamento em 25.2.2014, DJe de 28.3.2014).

Como se percebe, em todos esses casos o Supremo Tribunal Federal se desincumbiu do dever constitucional de fundamentação de suas decisões mediante enfrentamento explícito da semelhança dos motivos determinantes dos precedentes da SV 12 com os casos posteriores nos quais ela foi tida como aplicável, cumprindo com as exigências, antes implícitas no art. 93, IX, da Constituição brasileira de 1988, agora explicitadas no inciso $\mathrm{V}$ do $\S 1^{\circ}$ do art. 489 do $\mathrm{CPC} / 15$.

Finalmente, pende de apreciação Recurso Extraordinário, com repercussão geral já reconhecida no plenário virtual do STF, onde se discute a validade ou não da cobrança de taxa de matrícula e de mensalidades em curso de especialização lato sensu ofertado por universidade pública (STF, RE 597.854, Rel. Min. Edson Fachin).

Nesse julgamento, a Suprema Corte haverá de enfrentar o dever de distinção dos motivos determinantes da SV 12, se for o caso, por força do quanto disposto no art. 93, IX, da Constituição brasileira, e, agora, também no art. 927, § $1^{\circ}$, combinado com o art. 10 e com o art. $489, \S 1^{\circ}$, incisos V e VI, do CPC/15.

\section{CONSIDERAÇÕES FINAIS}

Muito embora desde 1988, com a promulgação da Constituição da República Federativa do Brasil, já fosse garantia constitucional do cidadão o dever de fundamentação das decisões judiciais, como se vê da análise de decisões emanadas do Supremo Tribunal Federal sobre a aplicação da Súmula Vinculante $\mathrm{n}^{\circ} 12 \mathrm{ou}$ da distinção de casos a ela relativos, é certo que com a recepção do Código de Processo Civil de 1973, 
Revista Eletrônica de Direito Processual - REDP.

Rio de Janeiro. Ano 10. Volume 17. Número 2. Julho a Dezembro de 2016

Periódico Semestral da Pós-Graduação Stricto Sensu em Direito Processual da UERJ

Patrono: José Carlos Barbosa Moreira. ISSN 1982-7636. pp. 101-119

www.redp.uerj.br

então vigente, vinha-se admitindo um padrão médio ${ }^{21}$ de justificação para as decisões

judiciais em geral, notadamente para questões que não acorressem à Suprema Corte.

Contudo, a partir da vigência do Código de Processo Civil de 2015, pode-se afirmar que aquela garantia foi concretizada mediante um padrão máximo de justificação interna e externa das decisões judiciais, sobretudo por força da implementação de um sistema de precedentes no direito brasileiro.

A análise da SV 12 no direito brasileiro serviu para enfrentar os temas primordiais daquele padrão máximo de fundamentação das decisões judiciais conectada com o regime jurídico constitucional e processual dos precedentes judiciais, sendo certo que a inserção dessa técnica no CPC/15, própria da common law, mas inevitável diante do intercâmbio cultural crescente com os países de civil law ${ }^{22}$, em muito contribuirá para a necessária segurança jurídica, seja no aspecto objetivo da estabilidade das relações jurídicas, seja no aspecto subjetivo, próprio da confiança dos cidadãos no sistema de Justiça, e para a igualdade de todos perante a norma jurídica, enquanto resultado da interpretação do texto legal.

\section{REFERÊNCIAS BIBLIOGRÁFICAS}

ÁVILA, Humberto. Teoria da Segurança Jurídica. 3. ed. São Paulo: Malheiros, 2014.

BARROSO, Luis Roberto. O Controle de Constitucionalidade no Direito Brasileiro. 6. Ed. São Paulo: Saraiva, 2014.

GRINOVER, Ada Pellegrini; DINAMARCO, Cândido Rangel; WATANABE, Kazuo (coord.). Participação e Processo. São Paulo: Revista dos Tribunais, 1988.

MACEDO, Lucas Buril de. Precedentes judiciais e o direito processual civil. Salvador: JusPodivm, 2015.

MARINONI, Luiz Guilherme. Precedentes Obrigatórios. São Paulo: Editora Revista dos Tribunais, 2010.

NUNES, Dierle; BAIA, Alexandre Melo Franco. "Precedentes no CPC-2015: por uma

\footnotetext{
${ }^{21}$ Afirmação que se faz no contexto das instâncias ordinárias brasileiras, conforme nota 2 supra.

${ }^{22}$ Denomina-se esse fenômeno de mixagem de jurisdições (mixed jurisdictions), cf. NUNES, Dierle; BAIA, Alexandre Melo Franco. Precedentes no CPC-2015: por uma compreensão constitucionalmente adequada do seu uso no Brasil. In FREIRE, Alexandre; BARROS, Lucas Buril de Macedo; PEIXOTO, Ravi. Coletânea Novo CPC: Doutrina Selecionada, passim.
} 
Revista Eletrônica de Direito Processual - REDP.

Rio de Janeiro. Ano 10. Volume 17. Número 2. Julho a Dezembro de 2016

Periódico Semestral da Pós-Graduação Stricto Sensu em Direito Processual da UERJ

Patrono: José Carlos Barbosa Moreira. ISSN 1982-7636. pp. 101-119

www.redp.uerj.br

compreensão constitucionalmente adequada do seu uso no Brasil". In FREIRE,

Alexandre; BARROS, Lucas Buril de Macedo; PEIXOTO, Ravi. Coletânea Novo CPC:

Doutrina Selecionada. Salvador: JusPodivm, 2015.

TARUFFO, Michele. “Addio alla motivazione?" In Rivista Trimestrale di Diritto e

Procedura Civile, n.1, marzo 2014, p. 375-388.

. La motivación de la sentencia civil. Madrid: Editorial Trotta, 2011. 